\title{
Pengaruh Penerapan Permainan Produksi Kapal terhadap Hasil Belajar Matematika Siswa pada Tema Indahnya Kebersamaan di Kelas IV Sekolah Dasar Negeri 111 Pekanbaru
}

\author{
Rafika Elsa Oktaviani ${ }^{1}$, Melly Andriani ${ }^{2}$ \\ ${ }^{1,2}$ Program Studi Pendidikan Guru Madrasah Ibtidaiyah, Universitas Islam Negeri Sultan Syarif Kasim Riau \\ e-mail: Rafikaelsaoktaviani@gmail.com
}

\begin{abstract}
This research had aimed to determine there was or no the effect application of Sheep production Games toward Math Learning Result of Students. This research was Quasi experiment research used post test only Design with nonequivalent group. The Sampling technique used random sampling. The Population of this research was all of IV grade students of Primary School 111 Pekanbaru that consisted of 4 classes and the number of students was 140. The result of homogeneity test obtained four classes had similar ability or same basic ability (homogeny). Based on the result of the data from value of post test and analyzed, test data that was used Liliefors showed that $L_{\text {count }}<L_{\text {table }}$ so that can be concluded the data from population that has normal distribution. The post data that used homogeneity showed that $x_{\text {count }}^{2}<x_{\text {table }}^{2}$ or $0,00414<3,84$, so variances was homogeny. After normal and homogeny data then continued to analyzed the data used $t$-test. It was obtained value of $t_{\text {count }}=2,750$ it mean $t_{\text {count }}$ is greater than $t_{\text {table }}$ at significance level of $5 \%$ or $1 \%$ with $d f=72$. In the table was not be found $d f=72$, so that using $d f$ that close to 72 namely $d f=70$. If obtained $t_{\text {table }}$ at significance level of $5 \%$ and $1 \%$ namely 2,00 and 2,65. It means that $t_{\text {count }}$ was greater than $t_{\text {table }}$ so concluded $\mathrm{Ho}$ is rejected and $\mathrm{Ha}$ is accepted, number of effect 9,76\%. So that it can be concluded that there is effect of learning that apply sheep production toward math learning result of students on the term of the beauty of togetherness at IV Grade of Primary School 111 Pekanbaru.
\end{abstract}

Keywords: Application of Sheep production Games, Result of Students

\section{PENDAHULUAN}

Guru memiliki prilaku dan kemampuan untuk mengembangkan siswanya secara optimal guru juga dituntut mampu menyajikan pembelajaran yang bukan semata-mata mentransfer pengetahuan, keterampilan, dan sikap, tetapi juga memiliki kemampuan meningkatkan kemandirian siswa (Mardia Hayati, 2012: 1). Guru sebagai pendidik juga harus bisa menjadi teladan yang baik bagi peserta didik. Guru merupakan model yang tindakannya dicontoh oleh peserta didik, maka pada peran ini guru harus memiliki kepribadian yang patut diteladani. Bagi peserta didik di sekolah dasar, segala tindak tanduk guru menjadi sorotan bagi mereka. Dalam Islam guru terbaik yang menjadi suri tauladan adalah Rasulullah. Sebagaimana firman Allah di dalam Al-qur'an surat al-ahzab ayat 21yang berbunyi: 


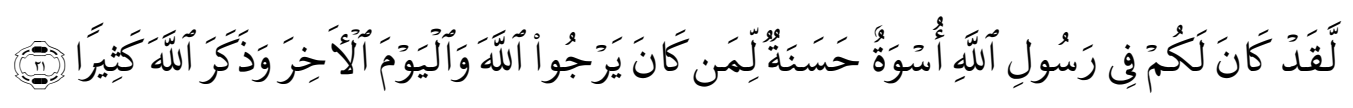

Artinya: Sesunggubnya telah ada pada diri Rasulullah itu suri teladan yang baik bagimu yaitu bagi
orang yang mengharap rahmat Allah dan kedatangan hari kiamat dan dia banyak menyebut Allah.
(QS. Al-Abzab:21)

Setiap guru pasti menginginkan siswanya untuk memperoleh hasil belajar yang baik dan sesuai dengan tujuan pembelajaran. Untuk mencapai hasil belajar yang sesuai dengan tujuan pembelajaran memang tidak mudah, guru sebagai pendidik harus merancang strategi yang tepat. Setiap sekolah tentunya menginginkan hasil belajar yang optimal pada tiap pelajaran yang diajarkan. Tidak hanya guru yang menginginkan siswanya untuk memperoleh hasil belajar yang baik dan sesuai dengan tujuan pembelajaran, tetapi setiap siswa juga berkeinginan untuk berhasil dalam kegiatan belajar. Keberhasilan ini menjadi kebanggaan bagi dirinya, orang tua maupun lingkungan tempat tinggalnya. Salah satu indikator keberhasilan siswa dalam proses pembelajaran adalah dengan mendapatkan hasil belajar yang baik. Dapat dikatakan bahwa keberhasilan guru dalam melaksanakan kegiatan pembelajaran akan tercemin dari hasil belajar yang akan dicapai siswa. Artinya semakin baik pelaksanaan pembelajaran, maka hasil belajar siswa juga akan semakin baik. Sebaliknya, semakin kurang pelaksanaan pembelajaran, maka hasil belajar siswa juga semakin rendah.

Salah satu mata pelajaran yang diajarkan di sekolah dasar yaitu matematika. Matematika berarti ilmu pengetahuan yang didapat dengan berfikir atau bernalar matematika lebih menekankan kegiatan dalam rasio atau penalaran. Dalam pembelajaran anak usia SD/MI adalah anak yang berada pada usia sekitar 7-12 tahun. Menurut Piaget anak usia sekitar ini masih berfikir pada tahap operasi konkrit (Melly dan Mimi, 2013: 2). Ciri-ciri anak pada tahap ini dapat memahami operasi logis dengan bantuan benda-benda konkret. Karena matematika merupakan ilmu yang abstrak maka untuk memberikan pemahaman konsep yang abstrak guru perlu melakukan beberapa hal (Melly dan Mimi, 2013: 17).

Selain itu, hendaknya anak didik dilatih bekerja sendiri atau turut aktif selama pembelajaran berlangsung misalnya; mengadakan berbagai percobaan (Melly dan Mimi, 2013: 18). Kenyataannya matematika memiliki citra negatif bagi siswa. Yaitu hal yang menakutkan, sulit, membuat pusing dan sederet kesan negatif lainnya. Bahkan dalam proses pembelajaran, matematika adalah mata pelajaran yang tidak disukai oleh siswa karena sulitnya. Dalam kegiatan pembelajaran, guru berperan sebagai fasilitator belajar dan siswa berperan sebagai individu yang belajar. Oleh karena itu, usaha-usaha yang dilakukan guru akan sangat mempengaruhi keberhasilan proses pembelajaran (Agus N. Cahyo, 2013: 239).

Berdasarkan hasil pengamatan yang peneliti lakukan pada siswa kelas IV Sekolah Dasar Negeri 111 Pekanbaru, proses pembelajaran matematika siswa kurang aktif dan hanya beberapa siswa yang dapat memahami materi yang disampaikan oleh pendidik. Pada saat proses pembelajaran guru hanya memberikan contoh-contoh soal yang tidak konkrit. Setelah guru menerangkan, lalu guru memberikan tugas kepada siswa sesuai dengan yang diterangkan oleh guru tersebut. Hal ini berdampak pada hasil kerja siswa yang masih 
tergolong rendah, dilihat dari gejala berikut; (1) Dari 36 orang siswa terdapat 21 siswa atau 61\% siswa yang tidak mencapai KKM yang ditetapkan yaitu 70. (2) Ketika diberikan Ulangan Harian terdapat 22 siswa atau $(63 \%)$ yang mendapatkan nilai di bawah KKM yaitu 70. Dan hanya 14 siswa yang mencapai nilai KKM. (3) Ketika diberikan soal cerita, siswa sulit untuk menyelesaikan soal cerita, merubah soal cerita kedalam bentuk matematika.

Berdasarkan fenomena ataupun gejala di atas, terlihat bahwa hasil belajar siswa pada mata pelajaran matematika masih tergolong rendah. Agar aktivitas pembelajaran yang dilakukan guru lebih terarah dan hasil belajar siswa meningkat pada mata pelajaran matematika, akan lebih baik guru menerapkan strategi, teknik, pendekatan, model, ataupun permainan dalam pembelajaran matematika yang tepat. Untuk itu dalam penelitian ini peneliti menerapkan permainan produksi kapal. Permainan produksi kapal merupakan permainan yang membuat siswa dapat memahami suatu materi yang bersifat abstrak menjadi konkret melalui kegiatan belajar dan bermain. Dalam permainan produksi kapal siswa dapat memainkan peran.

Berdasarkan latar belakang yang telah diuraikan tersebut, maka peneliti tertarik untuk meneliti masalah tersebut, dengan judul penelitian "Pengaruh Penerapan Permainan Produksi Kapal Terhadap Hasil Belajar Matematika Siswa pada Tema Indahnya Kebersamaan di Kelas IV SDN 111 Pekanbaru". Tujuan penelitian ini adalah: "untuk mengetahui apakah ada pengaruh yang signifikan dari penerapan permainan produksi kapal terhadap hasil belajar matematika siswa di Sekolah Dasar Negeri 111 Pekanbaru".

\section{METODOLOGI}

Penelitian ini dilaksanakan pada semester ganjil tahun ajaran 2015/2016 dan dilakukan di kelas IV SDN 111 Pekanbaru. Subjek dalam penelitian ini adalah siswa SDN 111 Pekanbaru kelas IV. Sedangkan objek dalam penelitian adalah permainan produksi kapal terhadap hasil belajar matematika pada tema indahnya kebersamaan.

Populasi dalam penelitian ini adalah seluruh siswa kelas IV SDN 111 Pekanbaru semester ganjil tahun ajaran 2015/2016 yang berjumlah 141 siswa. Teknik pengambilan sampel yang digunakan adalah random sampling. Sampel dilakukan berdasarkan informasi dari sekolah yang menyatakan dua kelas memiliki kemampuan yang tidak jauh berbeda. Namun, untuk membuktikan informasi tersebut perlu dilakukan uji statistik dengan menggunakan uji homogenitas dari nilai pretest yang diberikan. Setelah dilakukan uji homogenitas pengolahan data menunjukkan bahwa keempat kelas memiliki kemampuan yang tidak jauh berbeda atau kemampuan dasar yang sama (homogen). Selanjutnya kedua kelas dipilih secara acak sebagai kelas kontrol dan kelas eksperimen. Sampel dalam penelitian ini siswa kelas IV A sebagai kelas eksperimen dan IV C sebagai kelas kontrol.

Bentuk desain penelitian ini adalah quasi eksperiment yang dipilih yaitu nonequivalent control group design. Karena dalam pelaksanaan penelitian tidak selalu memungkinkan untuk melakukan seleksi subjek secara acak, karena subjek secara alami telah terbentuk dalam satu kelompok yang utuh (naturally formad intact group), seperti kelompok siswa dalam satu kelas (Sugiyono, 2009: 116). Alasan lainnya yaitu peneliti tidak mampu mengontrol semua variabel yang dapat mempengaruhi hasil belajar siswa. 
Bentuk nonequivalent control group design hampir sama dengan pretest-postest control group design, hanya saja pada desain ini kelompok eksperimen maupun kelompok kontrol tidak dipilih secara random. Kelompok kelas eksperimen diberikan perlakuan yaitu dipengaruhi oleh model permainan produksi kapal, sedangkan kelas kontrol diberi pelajaran dengan metode konvensional.

Keterangan:

$\mathrm{O}_{1}=$ nilai pretest kelas eksperimen

$\mathrm{O}_{2}=$ nilai posttest kelas kontrol

$\mathrm{O}_{3}=$ nilai pretest kelas eksperimen

$\mathrm{O}_{4}=$ nilai postest kelas kontrol

$\mathrm{X}=$ penerapan model permainan produksi kapal

Nilai pretest dan postest yang dimaksud adalah nilai yang menunjukkan hasil belajar siswa. Maka pengaruh model permainan produksi kapal terhadap hasil belajar matematika siswa pada tema indahnya kebersamaan dapat dihitung dengan cara $\left(\mathrm{O}_{2}-\mathrm{O}_{1}\right)-\left(\mathrm{O}_{4}-\mathrm{O}_{3}\right)$.

\begin{tabular}{|ccc|}
\hline$O_{1}$ & $X$ & $O_{2}$ \\
$O_{3}$ & & $O_{4}$ \\
\hline
\end{tabular}

Teknik pengumpulan data yang digunakan dalam penelitian ini adalah dokumentasi, observasi, dan tes. Dokumentasi ini dilakukan untuk mengetahui sejarah sekolah, keadaan guru dan siswa, sarana dan prasarana yang ada di SDN 111 Pekanbaru dan data tentang hasil belajar siswa. Metode observasi dilakukan untuk mengetahui bagaimana pembelajaran matematika yang berlangsung di kelas.

Ada dua jenis tes yang dilakukan dalam penelitian ini, yaitu tes kemampuan awal (pretest) dan postest. Validitas tes yang digunakan dalam penelitian ini yaitu validitas isi. Pretes diberikan kepada kelas populasi untuk menentukan uji homogenitas, pengujian homogenitas diuji dengan rumus uji Bartlett. Teknik analisis data yang digunakan dalam penelitian ini adalah tes " $\mathrm{t}$ ". Tes " $\mathrm{t}$ " merupakan salah satu uji statistik yang digunakan untuk mengetahui ada atau tidaknya perbedaan yang signifikan dari dua buah mean sampel (dua buah variabel yang dikomparatifkan). Sebelum dilakukan uji tes ' $\mathrm{t}$ ' maka yang harus dilakukan dengan melakukan uji normalitas dengan metode Liliefors.

\section{HASIL DAN PEMBAHASAN}

\section{Hasil Penelitian}

Hasil penelitian yang mencakup uji homogenitas populasi dan hasil belajar siswa. Perbedaan hasil belajar siswa yang menggunakan permainan produksi kapal dan yang menggunakan metode konvensional.

\section{Uji Homogenitas Populasi}

Uji homogenitas data diambil dari nilai pretest. Hasil uji homogenitas populasi terangkum pada tabel 1. 
Tabel 1. Uji Homogenitas Bartlet

\begin{tabular}{cccccccc}
\hline No & Sampel & $\mathbf{N}$ & Mean & dk=n-1 & $\mathbf{S}_{\boldsymbol{i}}$ & Log $\mathbf{S}_{\boldsymbol{i}}$ & Dk. Log S \\
\hline 1 & IV $^{\mathrm{a}}$ & 36 & 57,36 & 35 & 7,856 & 0,895201 & 31,332035 \\
2 & IV $^{\mathrm{b}}$ & 35 & 59,71 & 34 & 9,332 & 0,969974 & 32,979116 \\
3 & IV $^{\mathrm{c}}$ & 36 & 58,19 & 35 & 9,731 & 0,988157 & 34,585495 \\
4 & IV $^{\mathrm{d}}$ & 34 & 56,02 & 33 & 10,132 & 1,005695 & 33,187935 \\
\hline Jumlah & 4 & & & 137 & & & 132,084581 \\
\hline
\end{tabular}

Dari perhitungan ternyata $x^{2}{ }_{\text {hitung }}<x^{2}$ tabel atau $0,621<7,815$, maka variansvarians adalah homogen. Dari keempat kelas sampel terlihat bahwa, semua kelas homogen. Karena keempat kelas homogen, maka untuk melakukan pemilihan sampel dilakukan dengan teknik random. Setelah dilakukan terpilihlah kelas a dan kelas c sebagai sampel dalam penelitian. Kelas a sebagai kelas eksperimen dan kelas c sebagai kelas kontrol. tabel 2 .

Uji normalitas terhadap data postest yang peneliti peroleh, data dapat dilihat pada

\section{Tabel 2. Uji Normalitas}

\begin{tabular}{cccc}
\hline Kelas & $\mathbf{L}_{\text {hitung }}$ & $\mathbf{L}_{\text {tabel }}$ & Kriteria \\
\hline Eksperimen & 0,0989 & 0,147 & Normal \\
Kontrol & 0,115 & 0,147 & Normal \\
\hline
\end{tabular}

Berdasarkan hasil penelitian $\mathrm{L}_{\text {hitung }}<\mathrm{L}_{\text {tabel }}$ maka dapat dikatakan bahwa data berasal dari populasi yang berdistribusi normal.

Uji homogenitas yang peneliti lakukan adalah uji Bartlet. Data diambil dari nilai posttest. Hasil uji homogenitas hasil belajar terangkum pada tabel 3.

Tabel 3. Tabel Uji Homogenitas Bartlet

\begin{tabular}{|c|c|c|c|c|c|c|c|}
\hline No & Sampel & $\mathbf{N}$ & Mean & $\mathrm{dk}=\mathrm{n}-1$ & $\mathbf{S}_{\mathrm{i}}$ & $\log S_{i}$ & Dk.Log $S_{i}$ \\
\hline 1 & $\mathrm{IV}^{\mathrm{a}}$ & 36 & 82,25 & 35 & 13,359 & 1,125773 & 39,40205 \\
\hline 2 & $\mathrm{IV}^{\mathrm{c}}$ & 36 & 71,11 & 35 & 12,922 & 1,111329 & 38,89651 \\
\hline Jumlah & 2 & & & 70 & & & 78,29856 \\
\hline
\end{tabular}

Dari perhitungan ternyata $x^{2}$ hitung $<x^{2}$ tabel atau $0,00414<3,84$, maka variansvarians adalah homogen.

Kesimpulan: analisis uji komparatif dapat dilanjutkan

Seteleh data homogen dan normal, kemudian dilanjutkan analisis data dengan tes " $\mathrm{t}$ " dapat menggunakan uji statistik Compare Mare Independent Sampel Test. Hasil perhitungan selengkapnya dapat dilihat pada tabel 4.

Tabel 4. Uji Tes “t”

\begin{tabular}{ccccccc}
\hline Kelas & Perbedaan & $\mathbf{t}_{\text {hitung }}$ & Df & $\mathbf{t}_{\text {tabel } 5 \%}$ & $\mathbf{t}_{\text {tabel 1\% }}$ & $\mathbf{H}_{\mathbf{0}}$ \\
\hline Eksperimen & $82,36>71.11$ & 2,750 & 72 & 2,00 & 2,65 & Tolak
\end{tabular}

Kontrol

Berdasarkan tabel 4 dapat diambil keputusan yang dilakukan dengan cara membandingkan nilai thitung dengan tabel, dengan ketentuan sebagai berikut: 
Jika thitung $<t_{\text {tabel }}$ maka $\mathrm{H}_{\mathrm{o}}$ diterima dan $\mathrm{H}_{\mathrm{a}}$ ditolak

Jika thitung $>$ tabel maka $\mathrm{H}_{\mathrm{o}}$ ditolak dan $\mathrm{H}_{\mathrm{a}}$ diterima

Nilai thitung $=2,750$ berarti bahwa thitung lebih besar dari tabel pada taraf signifikan $5 \%$ maupun taraf signifikan $1 \%$ dengan $\mathrm{df}=72$. Dalam tabel tidak terdapat $\mathrm{df}=72$, maka dari itu digunakan $\mathrm{df}$ yang mendekati 72 yaitu $\mathrm{df}=70$. Dengan $\mathrm{df}$ diperoleh dari tabel pada taraf signifikan 5\% dan 1\% sebesar 2,00 dan 2,65. Ini berarti thitung $>t_{\text {tabel, }}$ maka diputuskan bahwa $\mathrm{H}_{\mathrm{o}}$ ditolak dan $\mathrm{H}_{\mathrm{a}}$ diterima. Dengan demikian dapat disimpulkan bahwa terdapat pengaruh pembelajaran yang menerapkan permainan produksi kapal terhadap hasil belajar siswa. Untuk perhitungan lebih lanjut dapat dilihat pada lampiran $\mathrm{I}_{1}$.

Untuk menentukan peningkatan hasil belajar siswa dilakukan dengan menghitung koefisien determinasi.

$$
\begin{aligned}
r^{2} & =\frac{t^{2}}{t^{2}+n-2} \\
r^{2} & =\frac{(2,750)^{2}}{(2,750)^{2}+72-2} \\
& =\frac{(7,5625)}{7,5625+70} \\
& =\frac{7,5625}{77,5625} \\
r^{2} & =0,097502
\end{aligned}
$$

Untuk menentukan persentase peningkatan (koefisien pengaruh)

$$
\begin{aligned}
\mathrm{KP} & =\mathrm{r}^{2} \times 100 \% . \\
& =0.097502 \times 100 \% \\
& =9,7502 \% \\
& =9,76 \%
\end{aligned}
$$

Jadi, besar pengaruh penerapan permainan produksi kapal sebesar 9,76\%.

\section{KESIMPULAN}

Berdasarkan hasil dari penelitian hasil belajar siswa pada materi operasi hitung campuran bilangan bulat menunjukkan hasil belajar kelas yang menggunakan permainan produksi kapal lebih baik daripada hasil belajar kelas konvensional. Sebagaimana yang dikatakan Sugiyono bahwa jika kelompok treatmen lebih baik daripada kelompok kontrol, maka perlakuan yang diberikan pada kelompok treatmen berpengaruh positif (Sugiono, 2010: 159).

Berdasarkan hasil penelitian dapat diambil kesimpulan terdapat pengaruh penerapan permainan produksi kapal terhadap hasil belajar siswa. Nilai thitung $=2,750$ berarti bahwa thitung lebih besar dari tabel pada taraf signifikan 5\% maupun taraf signifikan $1 \%$ dengan $\mathrm{df}=72$. Dalam tabel tidak terdapat $\mathrm{df}=72$, maka dari itu digunakan $\mathrm{df}$ yang mendekati 72 yaitu $d f=70$. Dengan df diperoleh dari tabel pada taraf signifikan $5 \%$ dan $1 \%$ sebesar 2,00 dan 2,65. Ini berarti thitung $>t_{\text {tabel, }}$ maka diputuskan bahwa $\mathrm{H}_{\mathrm{o}}$ ditolak dan $\mathrm{H}_{\mathrm{a}}$ diterima.

Dengan demikian hasil analisa ini mendukung rumusan masalah yang diajukan yaitu terdapat pengaruh penerapan permainan produksi kapal terhadap hasil belajar siswa. Besar pengaruh permainan produksi kapal terhadap hasil belajar siswa SDN 111 di kelas IV adalah sebesar $9,76 \%$. 
Hal ini dimungkinkan karena pembelajaran telah berubah dari paradigma pembelajaran yang berpusat pada guru kepada pembelajaran yang menekankan pada keaktifan siswa dalam berfikir sendiri maupun bersama teman dan membagi ide dengan temannya, kemudian melakukan diskusi. Penggunaan permainan produksi kapal memiliki kelebihan tersendiri yaitu ketika pelaksanaannya kontekstual, siswa memahami konsep melalui pengalaman nyata yang mereka alami.

\section{REFERENSI}

Andriani, M., \& Hariyani, M. (2013). Pembelajaran Matematika. Pekanbaru: Benteng Media.

Cahyo, A.N. (2013). Panduan Aplikasi Teori-Teori Belajar Mengajar Teraktual dan Terpopuler. Jogjakarta: DIVA Press (Anggota IKAPI).

Hajar, I. (2012). Panduan Lengkap Kurikulum Tematik. Yogyakarta: Diva Press.

Hayati, M. (2012). Desain Pembelajaran Berbasis Karakter. Pekanbaru: Al-Mujtahadah Press.

Iskandar. (2012). Psikologi Pendidikan. Jakarta: Anggota IKAPI.

Jaya, U.D. (2013). Media Pembelajaran Aktif. Bandung: Nuansa Cendekia.

Mujib, F., \& Rahmawati, N. (2012). Permainan Pendukung Edukatif Pembelajaran. Yogyakarta: Diva Press.

Nursalim. (2013). Pembelajaran Bahasa Indonesia Pendidikan Guru SD dan MI. Pekanbaru: Zanafa Publishing.

Purnomo, S.A., \& Novianty, R. (2013). Games for Fun Learning and Teaching. Bandung: Yrama Widya.

Rusman. (2010). Model-Model Pembelajaran Mengembangkan Profesionalisme Guru. Jakarta: Raja Grafindo Persada.

Slameto. (2010). Belajar dan Faktor-faktor yang Mempengaruhinya. Jakarta: Rineka Cipta.

Sugiyono.(2009). Metode Penelitian Pendidikan Kuantitatif Kualitatif R\&D. Bandung: Alfabetta.

Susanto, A. (2013). Teori Belajar dan Pembelajaran di Sekolah Dasar. Jakarta: Kencana Prenada Media Group.

Syah, M. (2008). Psikologi Belajar. Jakarta: PT Raja Grafindo.

Uno, H.B. (2011). Belajar dengan Pendekatan PAIKEM (Pembelajaran Aktif Inovatif Lingkungan Kreatif, Efektif, dan Menarik). Jakarta: Bumi Aksara. 